\title{
On the Law of Age and Area, in Relation to the Extinction of Species.
}

\author{
BY
}

\section{AGNES ARBER.}

D R. J. C. WILLIS, in the well-known series of papers in this and other journals in which he has elaborated his theory of 'Age and Area', has brought forward evidence for its validity which appears to me to be completely convincing. I am, however, unable to accept one subsidiary hypothesis, which Dr. Willis seems to regard as an integral factor in his scheme-the idea that, at least in the case of the Angiosperms, no extinction of species is now proceeding. This opinion he has repeatedly expressed. He wrote, for instance, in $1916^{1}$ that 'There is no evidence whatever that any of the angiospermous species of the Ceylon flora are dying out, and from analogy we may imagine this to be generally true'. He does indeed qualify this in 191 $8^{2}$ as far as to admit that ' there is a certain amount of geological evidence of former greater spread', but he seems to regard this as an exception of no real importance. Berry, ${ }^{3}$ on palaeobotanical grounds, and also Sinnott ${ }^{4}$ and Ridley, ${ }^{5}$ for more general reasons, have controverted Willis's view that no extinction is taking place among the Flowering Plants, and have expressed the opinion that certain members of this group are dying out at the present day.

When we look at the matter broadly, and consider living things as a whole, it becomes abundantly clear that extinction both of plant and animal species has occurred on a vast scale in the course of bygone geological epochs. I fancy that those palaeontologists who have paid the closest attention to these questions would be the least likely to accept Willis's contention that extinction in the past has been due almost entirely to catastrophes of some kind, or to great climatic changes. ${ }^{6}$ Even if we follow Willis in narrowing the issue down to Angiosperms, we must admit that there is no apparent reason for supposing them privileged to escape the universal fate. It might possibly be maintained that at the present day the Angiosperms are a dominant group entirely on the up-grade, in which extinction has not yet begun. But this position is refuted by certain

1 Willis, J. C. (1916).

4 Sinnott, E. W. (1917).
2 Willis, J. C. (1918).

${ }^{5}$ Ridley, H. N. (1916).
${ }^{3}$ Berry, E. W. $\left(1917^{\mathbf{l}}\right)$.

${ }^{6}$ Willis, J. C. (1918).

[Annals of Botany, Vol. XXXIII. No. CXXX. April, r919.] 
palaeobotanical evidence which can scarcely be gainsaid. For the sake of brevity I will cite one instance only. Professor Berry, ${ }^{1}$ by bringing together the evidence of Cretaceous and Tertiary fossils, has established that the genus Nelumbo, which is now represented by two species only, occurring respectively in Asia and America, had formerly a cosmopolitan range, including Greenland, Europe, and Africa. A number of the species which have been identified in the fossil state are now wholly extinct. A map showing the present and past distribution, which is included in Professor Berry's paper, brings vividly home to the reader the losses which this genus has suffered.

Having become convinced that Willis's position, in regard to the extinction of Angiospermic plants, was untenable, I sought to discover whether the validity of the Law of Age and Area must, in reality, stand or fall with the question of the dying out of species; the conclusion I have reached is that Willis's deductions regarding extinction depend upon a false assumption, and that they may be discarded without in any way affecting the truth of the law.

It will be remembered that Willis bases his hypothesis in the first instance upon a consideration of the degree of rarity of the various species constituting the flora of Ceylon. ${ }^{2}$ Following Trimen, he classifies the plants into a series of classes grading from 'Very Common' to 'Very Rare', and he uses the ingenious idea of awarding to each species ' marks' for rarity on a numerical scale. He writes, regarding the statistics based upon these classes, 'In what way the figures we have given are to be reconciled with any theory of the dying out of species I fail to understand'? When we scrutinize Willis's degrees of rarity more closely, we see that he uses the words 'common' and 'rare' in a slightly peculiar, ${ }^{4}$ though legitimate, sense, which he is careful expressly to define; he lays special stress on the fact that 'my figures ... refer to area occupied, not to commonness on the ground'.5 This being the case, it seems to me quite impossible to draw any conclusions for or against extinction from the figures in question; the whole matter hinges upon a confusion of thought between 'common' in the sense of widespread, and 'common' in the sense of numerically abundant. Willis apparently expects that those who differ from him on the question of extinction ought to be able to 'define a size of area above which species are to be regarded as growing, or below which as dying out' ${ }^{6}$ But what right have we to assume that the mechanism of extinction of a species is simply

1 Berry, E. W. $\left(1917^{2}\right)$.

2 Willis, J. C. (1915).

3 Willis, J. C. (1916).

4 The contention that Willis uses the word 'common' in a sense unusual among naturalists, is supported by the fact that Darwin (Origin of Species, 6th ed., 1894, p. 40) defines the most common species as those that 'abound most in individuals', and also draws a distinction between 'wide range' and 'commonness'.

5 Willis, J. C. (1917) (the italics are mine).

6 Willis, J. C. (1918). 
the converse of its mechanism of development, and hence consists in a progressive reduction of the area occupied? If we follow this assumption to its logical conclusion, we must suppose that each species in dying out steadily reduces its area, until it finally expires at its birthplace! This seems to be a fallacy comparable with the prevalent idea that structural degeneration is 'an actual retracing of steps until the point of departure is reached ' 1 There are, it is true, certain instances in which the area occupied by a dying species shrinks from the margin inwards; the Oxlip in East Anglia is an example, ${ }^{2}$ but such cases are probably wholly exceptional. This plant (Primula elatior, Jacq.) occupies a restricted region and is surrounded on all sides by Primroses (Primula vulgaris, Huds.), which do not penetrate into its area. Year by year the Oxlip and Primrose hybridize on the margin of the Oxlip's demesne; it seems that the Oxlip will ultimately be hybridized out of existence, and its place taken by the Primrose, which is present in such hordes that the loss which it suffers by hybridization is negligible. It appears to me, however, that, apart from such rare cases as this, the tangible evidence of the dying out of a species would more probably be a progressive decrease in 'commonness on the ground', while the total area over which the species spreads might remain unchanged almost to the last. This gradual decrease in abundance would be a subtle matter to gauge and to define, but it ought to come within the scope of ecological observations, when the progress of that branch of Botany has enabled connected records to be kept over a long series of years. Willis's methods, on the other hand-valuable as they are for their own purpose-are not adapted for giving any indication of the progress of extinction, if it takes place in such a way that the total area from which the species is known remains unaltered.

For the reasons which I have attempted to outline, I consider that-although Willis's.statistics undoubtedly substantiate the truth of his main hypothesis regarding Age and Area-they have no necessary bearing upon the question of the extinction of species.

BALFOUR LABORATORY, CAMBRIDGE.

1 There is a useful discussion of this and related questions in Demoor, J., Massart, J., and Vandervelde, E. (1899).

2 Christy, M. (1897). 


\section{LITERATURE CITED.}

Berry, E. W. $\left(1917^{1}\right)$ : A Note on the 'Age and Area' Hypothesis. Science, vol. xlvi, I9I7, pp. 539-40.

$\left(1917^{2}\right)$ : Geologic History indicated by the Fossiliferous Deposits of the Wilcox Group (Eocene) at Meridian, Mississippi. U.S. Geol. Surv., Prof. Paper 108 E, Shorter Contributions to General Geology, I917, pp. 6I-72, 3 pls., I text-fig., I map.

Christy, M. (1897): Primula elatior in Britain: Its Distribution, Peculiarities, Hybrids, and Allies. Journ. Linn. Soc. Bot., vol. xxxiii, I 897-8, pp. I 7 2-20I, I map.

Demoor, J., Massart, J., and Vandervelde, E. (1899): Evolution by Atrophy. Trans. by Mrs. Chalmers Mitchell. Intern. Sci. Ser., vol. lxxxvii, 1899.

Ridley, H. N. (1916): On Endemism and the Mutation Theory. Ann. Bot., vol. xxx, 1916, pp. $551-74$.

Sinnott, E. W. (1917): The 'Age and Area' Hypothesis and the Problem of Endemism. Ann. Bot., vol. xxxi, I9I 7 , pp. 209-16.

Willis, J. C. (1915): The Endemic Flora of Ceylon, with Reference to Geographical Distribution and Evolution in General. Phil. Trans. Roy. Soc., Lond., Ser. B, vol. ccvi, I9I 5, pp. 307-42, 4 text-figs.

(1916): The Evolution of Species in Ceylon, with reference to the Dying Out of Species. Ann. Bot., vol. xxx, I9I6, pp. I-23, 2 text-figs.

(1917): The Relative Age of Endemic Species and other Controversial Points. Ibid., vol. xxxi, I9I 7, pp. 189-208.

(1918): The Sources and Distribution of the New Zealand Flora, with a Reply to Criticism. Ibid., vol. xxxii, 1918, pp. 339-6\%. 


\section{$2 \mathrm{BHL}$ Biodiversity Heritage Library}

Arber, Agnes Robertson. 1919. "On the law of age and area, in relation to the extinction of species." Annals of botany 33, 211-214.

https://doi.org/10.1093/oxfordjournals.aob.a089710.

View This Item Online: https://www.biodiversitylibrary.org/item/235681

DOI: https://doi.org/10.1093/oxfordjournals.aob.a089710

Permalink: https://www.biodiversitylibrary.org/partpdf/320254

\section{Holding Institution}

Smithsonian Libraries

\section{Sponsored by}

Biodiversity Heritage Library

\section{Copyright \& Reuse}

Copyright Status: Not in copyright. The BHL knows of no copyright restrictions on this item.

This document was created from content at the Biodiversity Heritage Library, the world's largest open access digital library for biodiversity literature and archives. Visit BHL at https://www.biodiversitylibrary.org. 